\title{
A Scanning Electron Microscope Study of Myoepithelial Cells in the Intercalated Ducts of Rat Parotid and Exorbital Lacrimal Glands
}

\author{
By \\ Michitaka MURAKAMI, Toshikazu NAGATO and Hiroaki TANIOKA \\ Department of Oral and Maxillofacial Surgery, \\ School of Medicine, Ehime University, \\ 454 Shitsukawa, Shigenobu, Onsen-gun, Ehime 791-02, Japan \\ - Received for Publication, June 27, 1990- \\ Key Words: Myoepithelial cell, Exocrine gland, Intercalated duct, Scanning electron microscopy, Rat

\begin{abstract}
Summary: Myoepithelial cells in the intercalated ducts of rat parotid and exorbital lacrimal glands were examined by scanning electron microscopy. The basal surface of the intercalated ducts revealed myoepithelial cells running parallel with its long axis. These myoepithelial cells were linked with one another, forming a well-developed network, and numerous wrinkles running transversely were observed on the surface of the myoepithelial cells. Also, some myoepithelial cells in the terminal portion linked with those in the intercalated duct. Based on these findings, it is suggested that myoepithelial cells in the intercalated duct may function as a protective wall against constriction of the narrow lumen of the intercalated duct when it is subjected to pressure by the surrounding tissues.
\end{abstract}

Since Henle (1841) first reported the presence of smooth muscle-like cells around the ducts of the human mammary gland, numerous morphological studies on myoepithelial cells have been carried out by ironhematoxylin staining (Zimmermann, 1898), silver staining (Richardson, 1949) and histochemical techniques employing ALPase (Silver, 1954; Leeson, 1956; Garrett, 1973) and ATPase (Shear, 1964; Garrett and Harrison, 1970). Also, attempts have been made to elucidate the overall structure of myoepithelial cells in a number of exocrine glands, including the salivary gland. The ultrastructure of myoepithelial cells has been shown to resemble closely that of smooth muscle cells in the walls of blood vessels and the digestive tract (Ellis, 1965; Tamarin, 1966). It is also well known that myoepithelial cells contain the same contractile protein that is present in smooth muscle, as has been demonstrated by investigations using an actin- and myosin-specific fluorescent antibody method (Archer and Kao, 1968; Drenckhahn et al., 1977). In an earlier study, we observed certain exocrine glands, i.e., three major salivary, mammary and exorbital lacrimal glands in the rat under the scanning electron microscope utilizing a procedure which selectively removed extracellular connective tissue components and basal laminae in order to observe the non-free surface of cells and tissues. As reported previously, our study clarified the three-dimensional ultrastructure of myoepithelial cells in the terminal portion of each gland and demonstrated that a close correlation exists between the degree of development of the myoepithelial cells and the viscosity of the secretory products (Nagato et al., 1980).

Although the presence of myoepithelial cells in ducts is well known (Richardson, 1949; Tamarin, 1966; Alexander et al., 1973), studies based on scanning electron-microscopic observations have not been reported except for one investigation on the ducts of the rat mammary gland (Yoshida et al., 1980).

In the present study, the basal surface of intercalated ducts of rat parotid and exorbital lacrimal glands was visualized under the scanning electron microscope employing a slightly modified extracellular connective tissue component removal technique. As a result, several interesting findings concerning the threedimensional architecture of the myoepithelial cells in the intercalated duct were obtained. Also, an evaluation of the functions of the myoepithelial cells in the intercalated duct was made based on these findings.

Address all correspondence to: Dr. Michitaka Murakami, Department of Oral and Maxillofacial Surgery, School of Medicine, Ehime University, 454 Shitsukawa, Shigenobu, Onsen-gun, Ehime 791-02, Japan 


\section{Materials and Methods}

Parotid and exorbital lacrimal glands from SpragueDawley rats of both sexes, aged 3 to 6 months, were used for the study.

Glandular tissues removed from the rats under general anesthesia induced by intraperitoneal administration of pentobarbital sodium (Nembutal; 50 $\mathrm{mg} / \mathrm{kg}$ body weight) were immediately placed in Eagle's minimum essential medium (MEM), and then cut into small blocks with each side measuring less than $1 \mathrm{~mm}$. According to the method of Nagato et al. (1980), these unfixed fresh specimens were transferred to Eagle's MEM containing $300 \mathrm{U} / \mathrm{ml}$ of collagenase and 10 $\mathrm{TRU} / \mathrm{ml}$ of hyaluronidase, and allowed to undergo digestion at $37^{\circ} \mathrm{C}$ for $10-20 \mathrm{~min}$. The specimens were subsequently fixed in $3 \%$ phosphate-buffered glutaraldehyde at room temperature for $1 \mathrm{hr}$, and then hydrolyzed with $8 \mathrm{~N}$ hydrochloric acid at $60^{\circ} \mathrm{C}$ for 30 min. The bottle containing the specimens was shaken vigorously to break the tissues into small pieces. After a second hydrolysis at $37^{\circ} \mathrm{C}$ for $10-20 \mathrm{~min}$, the specimens were washed thoroughly in water, and treated for post-fixation in 1\% osmic acid. According to the usual method, the specimens were dehydrated through a graded series of ethanol followed by substitution of isoamyl acetate, critical point dried, coated with platinum, and observed under a Hitachi S-500A scanning electron microscope. Also, the entire basal surface area of the intercalated ducts and the area covered by myoepithelial cells were measured morphometrically with a Leitz texture analysis system to obtain a guide which would enable us to compare the degree of development of the myoepithelial cells in the intercalated ducts of each gland.

\section{Observations}

\section{Parotid gland}

Most of the intercalated ducts were detached from the striated ducts, since the specimens tended to break easily at the boundary between the intercalated and striated ducts during the extracellular connective tissue component removal process. The intercalated ducts measured 6-8 $\mu \mathrm{m}$ in diameter and approximately $20-25 \mu \mathrm{m}$ in length (Fig. 1), but some were as long as about $50 \mu \mathrm{m}$. The basal surface of the intercalated ducts revealed myoepithelial cells running along the long axis. The bodies of the myoepithelial cells were $4-5 \mu \mathrm{m}$ in width, and from both ends of the cell body a few primary processes of about $2 \mu \mathrm{m}$ in width extended parallel to the long axis of the duct. Additionally, a few secondary processes of about $1 \mu \mathrm{m}$ in width extended from the primary processes. These processes were linked with those of adjacent myoepithelial cells, forming a tight network on the basal surface of the duct (Fig. 2). On the other hand, wrinkles running at right angles to the long axis of the duct were observed on the surface of the body and the myoepithelial cells. The area covered by the myoepithelial cells accounted for about $60 \%$ of the total basal surface area of the intercalated duct.

\section{Exorbital lacrimal gland}

The intercalated ducts of the exorbital lacrimal glands were longer than those of the parotid gland, measuring 200-300 $\mu \mathrm{m}$ on average, but sometimes markedly long ones of about $500 \mu \mathrm{m}$ in length were seen (Fig. 3). Since the specimens tended to detach from the interlobular duct, it was difficult to observe the transitional area from the intercalated duct to the interlobular duct. The intercalated duct was $15-20 \mu \mathrm{m}$ in diameter near the interlobular duct, and thereafter gradually became smaller while branching a few times, finally reaching about $7 \mu \mathrm{m}$ at the transitional area to the terminal portion.

The basal surface of the intercalated duct revealed myoepithelial cells running parallel with its long axis. The myoepithelial cell body near the terminal portion was observed to be about $4 \mu \mathrm{m}$ in width, and from both ends of the cell body approximately two primary projections of about $1-2 \mu \mathrm{m}$ in width extended parallel to the long axis of the duct. Moreover, secondary projections of about $0.5-1 \mu \mathrm{m}$ in width extended from the primary projections. These secondary projections branched a few times, and then linked with those of adjacent myoepithelial cells to form a well-developed network on the basal surface of the duct (Fig. 4). Also, some myoepithelial cells in the terminal portion extended their projections to the intercalated duct and linked with projections of the myoepithelial cells in the intercalated duct (Fig. 5). Near the terminal portion, the area covered by the myoepithelial cells accounted for about $55 \%$ of the total basal surface area of the intercalated duct. On the other hand, near the interlobular duct, the projections of the myoepithelial cells were slightly wider, while the numbers of primary and secondary projections were somewhat smaller than those observed near the terminal portion (Fig. 6). The area covered by the myoepithelial cells accounted for about $60 \%$ of the total basal surface area, a ratio not very different from that near the terminal portion. Also, wrinkles arranged at right angles to the long axis of the duct were observed on the surface of the myoepithelial cell body and the projections (Figs. 4 and 6).

\section{Discussion}

Since Evan et al. (1976) introduced a procedure which selectively removed extracellular connective tissue 
components and basal laminae in the field of scanning electron microscopy for the observation of non-free surfaces of tissues and cells, several researchers have clarified the three-dimensional ultrastructure of myoepithelial cells in the terminal portion of various exocrine glands, including the salivary gland (Nagato, 1978; Abe, 1979; Brocco and Tamarin, 1979; Nagato et al., 1980; Nagai and Nagai, 1985). On the other hand, the three-dimensional structure of the basal surface of exocrine glands has been examined by reconstructing it from continuous sections (Tamarin, 1966), and by observing the ducts of the rat submandibular gland (Brocco and Tamarin, 1979) and mammary gland (Yoshida et al., 1980) from the basal side by scanning electron microscopy. However, no such study has been reported for the myoepithelial cells of the intercalated duct, and an anatomical reason is considered to be responsible for this. That is to say, since the outermost layer of the glandular lobule is occupied by the terminal portion, the intercalated ductal system exists in a much deeper area. In the present study, to the previously reported extracellular connective tissue component removal method for observing myoepithelial cells in the terminal portion, we added a new procedure for vigorously shaking the bottle containing the specimen in the middle of the acid treatment. This enabled us to visualize the duct inside the lobule under the scanning electron microscope, which led to the subsequent interesting findings obtained for the myoepithelial cells of the intercalated duct. Nevertheless, this shaking process not only removed the terminal portion in the outermost layer of the lobule, it also caused the specimens to break at the boundary between the intercalated duct and the striated or interlobular duct. The development of improved methods for exposing the basal surface of the duct is thus necessary in order to observe the transitional area from the terminal portion to the excretory duct via the intercalated, and striated or interlobular duct.

Nagato et al. (1980) reported that myoepithelial cells in the terminal portion of the submandibular, sublingual and exorbital lacrimal glands are stellate in shape, consisting of a central cell body and a number of ramifying cellular processes, whereas those in the lactating mammary gland have fewer processes and appear as a "spindle shape with some processes". In the same report, the ratio of the basal surface area of the terminal portion covered by myoepithelial cells to the total area was calculated as a guide for determining the degree of development of the myoepithelial cell network. The following ratios were obtained: $48 \%$ for the sublingual gland, $25 \%$ for the submandibular gland, $24 \%$ for the lactating mammary gland, and no myoepithelial cells in the terminal portion of the parotid gland. These results indicate that a close correlation exists between the degree of development of the myo- epithelial cell network and the viscosity of the secretory products. On the other hand, the present study demonstrated that the myoepithelial cells in the intercalated duct had a spindle-shaped cell body which was arranged parallel to the long axis of the duct. From both ends of the cell body, a few processes extended which ran almost parallel with the long axis of the duct, and they further branched into secondary and tertiary processes. These processes linked with those of adjacent cells to form a tight network of myoepithelial cells on the basal surface of the duct. The shape of the myoepithelial cells in the intercalated duct differed from that of those in the terminal portion which was stellate. The two types of exocrine glands observed in the present study produced secretory products of low viscosity, and it is interesting to note that the myoepithelial cells in the intercalated duct of both glands were morphologically similar and almost comparable as regards the ratios covering the basal surface.

The major function of the myoepithelial cells in the terminal portion may be related to the fact that their contraction produces pressure on the terminal portion, thereby accelerating the discharge of secretory products accumulated in the glandular lumen (Wiederman and Stone, 1962; Emmelin et al., 1968). Such a function is considered particularly important if the viscosity of the secretory products is high (Young and Van Lennep, 1977; Nagato et al., 1980). On the other hand, Tandler et al. (1970) proposed another function, viz., that sudden contraction might play a role in the rupture of the mucous granules at the apical surface of the mucosa cells. Furthermore, Emmelin et al. (1968) suggested the possibility that myoepithelial cells may play a role in preventing the terminal portion that is energetically synthesizing a secretory product from becoming swollen and being injured by its own secretory product. The function of the myoepithelial cells in the intercalated duct has been discussed by Garrett and Parsons (1973), who indicated that contraction of the myoepithelial cells induced shortening of the intercalated duct and expansion of the lumen, thereby enhancing the discharge of secretory products. Our current scanning electron microscopic observations demonstrated that the myoepithelial cells of both the terminal portion and intercalated duct are linked at their projections. This finding strongly suggests that the myoepithelial cells of the terminal portion and the intercalated duct function in concert to accelerate the discharge of secretory products. Myoepithelial cells in the terminal portion have already been shown to form fine wrinkles on the surface during contraction (Abe, 1979). In the present study, similar wrinkles running at right angles to the long axis of the duct were observed on the myoepithelial cells of the intercalated duct. This clearly indicates that the myofilaments of the myoepithelial cells in the intercalated duct are arranged in a specific direction to 
shorten the duct. Nevertheless, to verify whether a shortened intercalated duct and an enlarged lumen actually occur when myoepithelial cells are stimulated in the gland as it functions in vivo, the corresponding morphological changes must be observed directly. Also, the possibility cannot be excluded that the myoepithelial cells in the intercalated duct may play another role, as follows: if the terminal portion and the ductal system do not change their positional relationship substantially under any functional phase, in the intercalated ducts, particularly those considerably long ones observed in the exorbital lacrimal gland, isometric contraction might occur in the myoepithelial cells when they are stimulated. As a result, powerfully strained myoepithelial cell networks would form a wall on the basal surface of the intercalated duct. This wall is considered to be protective against constriction of the lumen of a narrow intercalated duct when it is subjected to pressure by the surrounding tissues.

\section{References}

1) Abe, J.: Scanning electron microscopic observations of the mammary gland myoepithelial cells of the rat under normal and experimental conditions. Kurume Med. J., 26: 303-310, 1979.

2) Alexander, J.H., Young, J.A., Van Lennep, E.W.: The ultrastructure of the duct system in the rat extraorbital lacrimal gland. Z. Zellforsch., 144: 453-466, 1973.

3) Archer, F.L., Kao, V.C.Y.: Immunohistochemical identification of actomyosin in myoepithelium of human tissues. Lab. Invest., 18: 669-674, 1968.

4) Brocco, S.L., Tamarin, A.: The topography of rat submandibular gland parenchyma as observed with S.E.M.. Anat. Rec., 194: 445-460, 1979.

5) Drenckhahn, D., Gröschel-Stewart, U., Unsicker, K.: Immunofluorescence-microscopic demonstration of myosin and actin in salivary glands and exocrine pancreas of the rat. Cell Tissue Res., 183: 273-279, 1977.

6) Ellis, R.A.: Fine structure of the myoepithelium of the eccrine sweat gland of man. J. Cell Biol., 27: 551-563, 1965.

7) Emmelin, N., Garrett, J.R., Ohlin, P.: Neural control of salivary myoepithelial cells. J. Physiol., 200: 539-546, 1968.

8) Evan, A.P., Dail, W.G., Dammrose, D., Palmer, C.: Scanning electron microscopy of cell surfaces following removal of extracellular material. Anat. Rec., 185: 433-446, 1976.

9) Garrett, J.R., Harrison, J.D.: Alkaline-phosphatase and adenosine triphosphatase histochemical reactions in the salivary glands of cat, dog and man, with particular reference to the myoepithelial ceils. Histochemie, 24: 214-229, 1970.

10) Garrett, J.R., Parsons, P.A.: Alkaline phosphatase and myoepithelial cells in the parotid gland of the rat. Histochem. J., 5: 463-471, 1973.

11) Henle, J.: Allgemeine Anatomie. In Vom Bau des menschlichen Körpers (Eds. Sommering), Leipzig, 1841. pp. 916-920. Cited from Radnor, C.J.P.: Myoepithelial cell differentiation in rat mammary glands. J. Anat., 111: 381-398, 1972.

12) Leeson, C.R.: Localization of alkaline phosphatase in the submaxillary gland of the rat. Nature, 178: 858-859, 1956.

13) Nagai, T., Nagai, M.: Scanning electron microscopy of the human submandibular gland. Arch. Otorhinolaryngol., 241: 265-266, 1985.

14) Nagato, T.: Scanning electron microscopical image of myoepithelial cells. J. Electron Microsc., 27: 235-236, 1978.

15) Nagato, T., Yoshida, H., Yoshida, A., Uehara, Y.: A scanning electron microscope study of myoepithelial cells in exocrine glands. Cell Tissue Res., 209: 1-10, 1980.

16) Richardson, K.C.: Contractile tissues in the mammary gland, with special reference to myoepithelium in the goat. Proc. Roy. Soc. B, 136: 30-45, 1949.

17) Shear, M.: Histochemical localization of alkaline phosphatase and adenosine triphosphatase in the myoepithelial cells of rat salivary gland. Nature, 203: 770, 1964.

18) Silver, I.A.: Myoepithelial cells in the mammary and parotid glands. J. Physiol., 125: 8-9, 1954.

19) Tamarin, A.: Myoepithelium of the rat submaxillary gland. J. Ultrastruct. Res., 16: 320-338, 1966.

20) Tandler, B., Denning, C.R., Mandel, I.D., Kutscher, A.H.: Ultrastructure of human labial salivary glands. III. Myoepithelium and ducts. J. Morphol., 130: 227-245, 1970.

21) Wiederman, J., Stone, M.L.: Effect of oxytocin on myoepithelium of the breast. J. Appl. Physiol., 17: 539-542, 1962.

22) Yoshida, H., Yoshida, A., Fukunishi, R., Nagato, T., Uehara, Y.: Scanning electron microscopy of 7,12-dimethylbenz(a)anthracene-induced mammary carcinoma in the female Sprague-Dawley rat. Virchows Arch. B Cell Path., 32: 105-108, 1980.

23) Young, J.A., Van Lennep, E.V.: Morphology and physiology of salivary myoepithelial cells. Int. Rev. Physiol., 12: 105-125, 1977.

24) Zimmerman, K.W.: Beiträge zur Kenntniss einiger Drüsen und Epithelien. Arch. Microsk. Anat., 52: 552-706, 1898. 

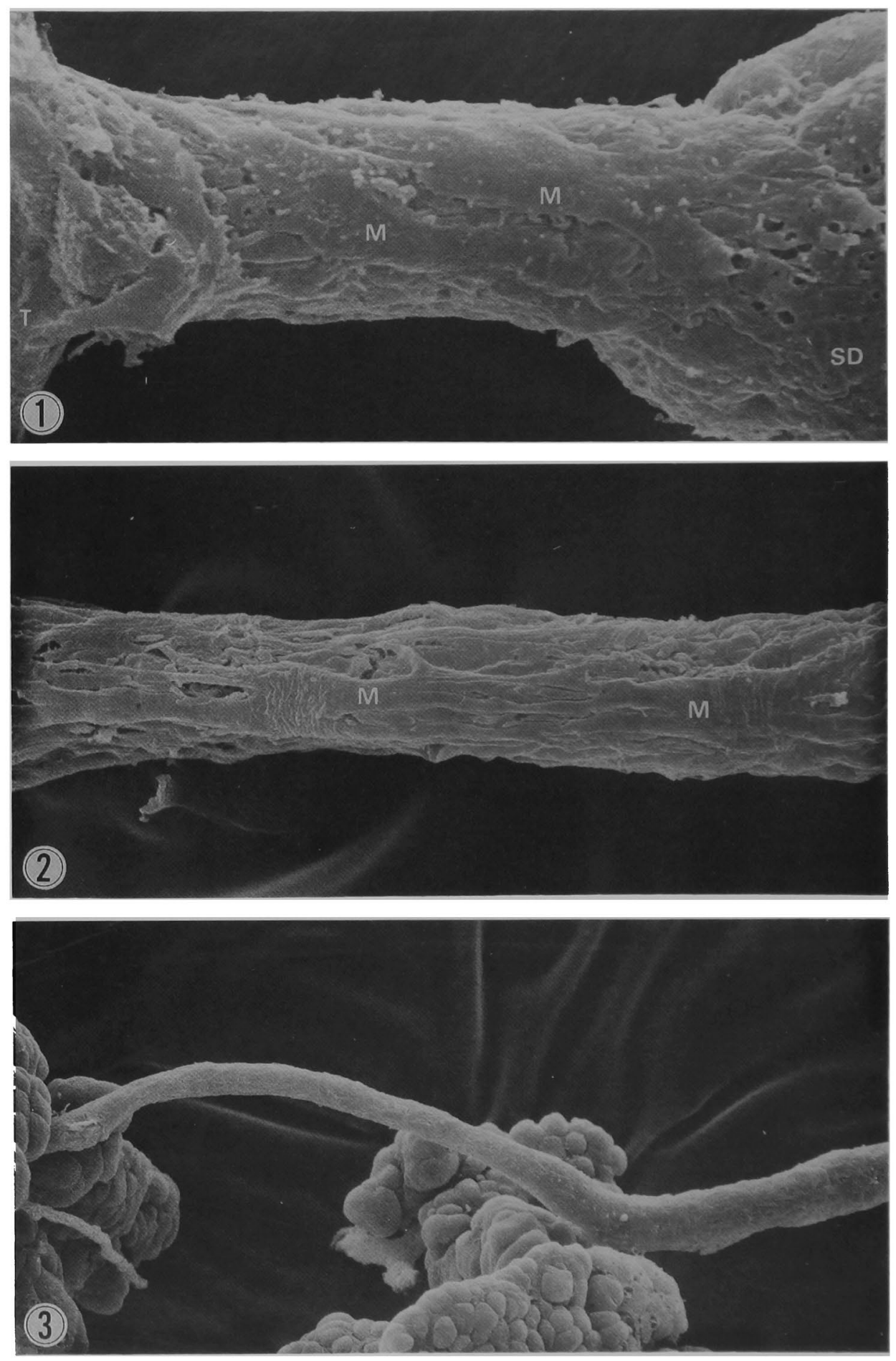

\section{Explanation of Figures}

\section{Plate I}

Fig. 1. Intercalated duct of the parotid gland. Myoepithelial cells (M) can been seen running along the long axis of the intercalated duct. T: terminal portion, SD: striated duct. $\times 4720$

Fig. 2. Intercalated duct of the parotid gland. Myoepithelial cells $(M)$ are linked with one another at their projections, forming a well-developed network. $\times 3360$

Fig. 3. Markedly long intercalated duct of the exorbital lacrimal gland, measuring approximately $500 \mu \mathrm{m}$ in length. $\times 560$ 
Plate II
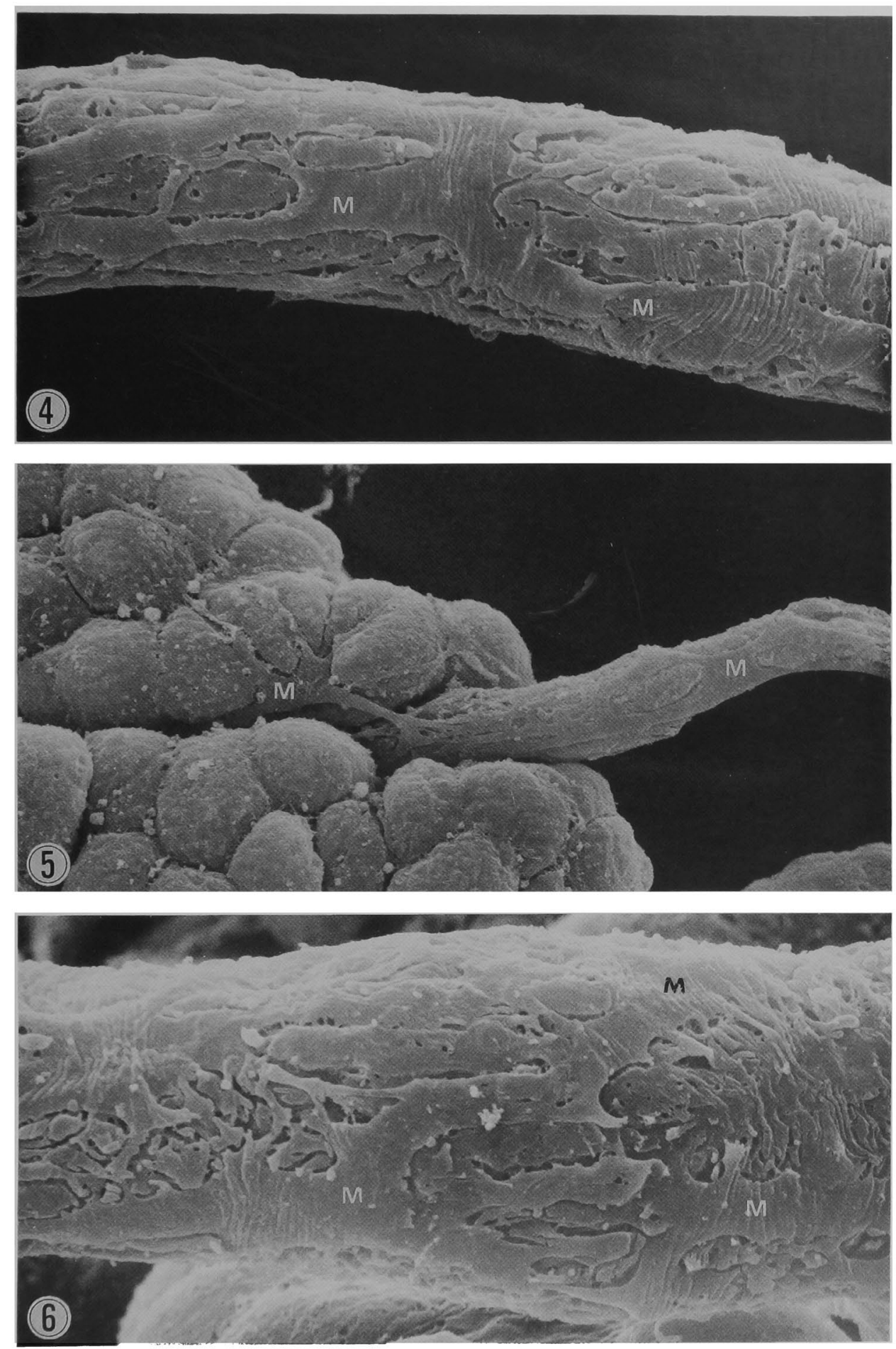

Plate II

Fig. 4. Myoepithelial cells (M) in the intercalated duct located near the terminal portion. Numerous wrinkles running transversely were observed on the surface of the myoepithelial cells. $\times 4420$

Fig. 5. At the boundary between the intercalated duct and the terminal portion, there are myoepithelial cells (M) in the terminal portion extending their projections and linking with those in the intercalated duct. $\times 1420$

Fig. 6. Myoepithelial cells (M) in the intercalated duct located near the interlobular duct. The projections of the myoepithelial cells are slightly wider than those observed near the terminal portion. $\times 4230$ 